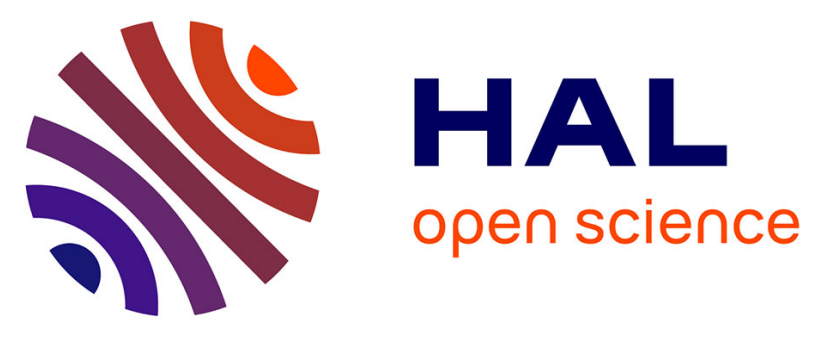

\title{
Biocorrosion detection by sulphur isotopic fractionation measurements
}

Sophie Grousset, Laurent Urios, S. Mostefaoui, Alexandre Dauzères, Didier Crusset, Valérie Deydier, Yannick Linard, Florence F. Mercier-Bion, Delphine D. Neff, Philippe Dillmann

\section{To cite this version:}

Sophie Grousset, Laurent Urios, S. Mostefaoui, Alexandre Dauzères, Didier Crusset, et al.. Biocorrosion detection by sulphur isotopic fractionation measurements. Corrosion Science, 2020, 165, pp.108386. 10.1016/j.corsci.2019.108386 . cea-02412940

\section{HAL Id: cea-02412940 https://hal-cea.archives-ouvertes.fr/cea-02412940}

Submitted on 16 Dec 2019

HAL is a multi-disciplinary open access archive for the deposit and dissemination of scientific research documents, whether they are published or not. The documents may come from teaching and research institutions in France or abroad, or from public or private research centers.
L'archive ouverte pluridisciplinaire HAL, est destinée au dépôt et à la diffusion de documents scientifiques de niveau recherche, publiés ou non, émanant des établissements d'enseignement et de recherche français ou étrangers, des laboratoires publics ou privés.

\section{(ㅇ)(1) $\$$}

Distributed under a Creative Commons Attribution - NonCommercial - NoDerivatives| 4.0 
S. GROUSSET ${ }^{1,4,5}$, L. URIOS ${ }^{2}$, S. MOSTEFAOUI ${ }^{3}$, A. DAUZERES ${ }^{4}$, D. CRUSSET $^{5}$, V. DEYDIER ${ }^{5}$, Y. LINARD ${ }^{5}$, P. DILLMANN ${ }^{1}$, F. MERCIER-BION $^{1}$ and D. NEFF $^{1}$

1: LAPA-IRAMAT, NIMBE, CEA, CNRS, Université Paris-Saclay, CEA Saclay 91191 Gif-sur-

Yvette France

2: IPREM-EEM, UMR 5254, Université de Pau et des Pays de l'Adour, 64013 Pau Cedex, France

3: IMPMC-COSMO, Museum National d'Histoire Naturelle, 75231 Paris Cedex 05, France

4: IRSN, PRP-DGE/SRTG/LETIS, B.P. 17, 92262 Fontenay aux Roses Cedex, France

5: Andra, Direction de la recherche et développement, 1-7 rue Jean-Monnet, 92298 Châtenay-Malabry

Cedex, France

Corresponding author: Sophie Grousset - sophie.grousset@alumni.enscp.fr

\title{
Highlights
}

- Iron sulphide are distributed at the micrometric scale in anoxic corr sion layers

- Sulphur isotopic fractionation determine the biotic/abioti origin of iron sulphide

- $\delta^{34} \mathrm{~S}_{\text {sulphides-sulphates }}$ is negative for iron sulphide of bacterial or gin

- $\delta^{34} \mathrm{~s}_{\text {sulphides-sulphates }}$ is close to zero for iron sulphide of inorganic origin

- NanoSIMS allows to measure the $\delta^{34} S$ of sulphides at the submicrometric scale

\begin{abstract}
This innovative tudy presents a local diagnosis approach based on nanoSIMS technique to determine the biotic/abioti origin of iron sulphides of (sub)micron size heterogeneously located in the corrosion product layers of iron. For iron coupons corroded in controlled conditions, negative $\delta^{34} \mathrm{~S}_{\text {sulphides-sulphates }}$ were btained in biotic conditions contrary to $\delta^{34} \mathrm{~S}_{\text {sulphides-sulphates }}$ obtained in abiotic ones. Th se results underline that nanoSIMS is a reliable local technique to detect the formation origin of (sub)micr $n$ iron sulphides. This successful methodology was then applied to a complex system representative of an iron corroded in the conditions similar to those of radioactive wastes storage in geological medium.
\end{abstract}

Keywords: microbiological corrosion, iron sulphide, sulphur isotopic fractionation, NanoSIMS

\section{Introduction}


Resistance of metallic alloys to anoxic corrosion in soil or in marine and subaquatic water is a major issue whether for industrial facilities $[1,2]$, geological nuclear waste storage $[3,4]$ or cultural heritage [5]. Among the parameters influencing the corrosion in these environments and the possible threat encountered in these contexts, the presence of bacteria is particularly important to be taken into account for the preservation and maintenance of the solicited metals [6-13]. Thus, to better understand the role of bacteria in iron corrosion to predictive modeling of iron anoxic corrosion, it is crucial to describe accurately the systems. Previous studies have shown that the corrosion product layers (CPL) resulting from iron anoxic corrosion are mainly composed of iron carbonates, siderite $\left(\mathrm{Fe}^{\mathrm{II}} \mathrm{CO}_{3}\right)[14$ 16] and sometimes chukanovite $\left(\mathrm{Fe}_{2}{ }_{2}(\mathrm{OH})_{2} \mathrm{CO}_{3}\right)[14,15]$, with discontinuous strips of magnetite $\left(\mathrm{Fe}^{\mathrm{II}, \mathrm{III}}{ }_{3} \mathrm{O}_{4}\right)$ [14-16]. Moreover, several studies related to the iron anoxic corrosion show the formation of iron/sulphur-containing compounds, especially iron sulphides, among the corrosion products $[5,17,18]$. These iron sulphides present in the CPL of iron may lead to important chang $\mathrm{s}$ in corrosion rates by inhibiting or accelerating corrosion processes [19-23]. Consequently, it is sen ial to determine the origin of these phases in order to achieve a more precise diagnosis on the formation of these corrosion products. This will allow to determine how far they endanger the mechanical sustainability of the concerned metals and to set-up adapted protection methods against corrosion $[24,25]$.

In sulphate-rich environments, iron sulphides are suspected o result from the action of sulphatereducing bacteria (SRB) that transform sulphates into sulphides [26 27]. However in sulphide-bearing environment as clay, iron sulphides may also result $\mathrm{f}$ om otally abiotic reaction pathways [28-32]. For instance, dissolution/reprecipitation of pyri e may occur leading to the production of iron sulphides [33]. It was observed that whatever the formation origin of the iron sulphides (abiotic or biotic), the same crystalline phases are involved, going from mackinawite $\mathrm{FeS}$ up to pyrite $\mathrm{FeS}_{2}$ through the intermediate phase greigite $\mathrm{Fe}_{4} \mathrm{~S}_{4}[22,28,34,35]$. Therefore the crystalline nature of the iron sulphides does not allow e id nce the formation origin of iron sulphides. The usual way to diagnose the formation origin $\mathrm{f}$ these sulphides is to determine the sulphur isotopic ratio $\mathrm{R}^{34} \mathrm{~S}$ defined as:

$$
R^{34} S=\frac{\text { Abundance of }{ }^{34} S}{\text { Abundance of }{ }^{32} S}
$$

In the ab ence of SRB, $R$ is known to be close to $\mathrm{R}^{34}$ Snatural of natural sulphur that is 0.04519 . On the con rary, when sulphato-reduction phenomenon occurs through a bacterial metabolism, because of in ra-cellular kinetic effects, SRB preferentially consume ${ }^{32} \mathrm{~S}$ of the sulphate. This phenomenon is explained by the fact that it is easier for bacteria to break the molecular bounds when sulphates are composed of the lighter sulphur isotope [36]. Therefore the residual sulphates of the medium become ${ }^{32} \mathrm{~S}$-depleted and ${ }^{34} \mathrm{~S}$-enriched and conversely the formed sulphides are ${ }^{34} \mathrm{~S}$-depleted. In presence of ferrous ions, originated from any sources, among them corrosion, this leads to the precipitation of iron sulphides that are also ${ }^{34}$ S-depleted [36-39]. Therefore, when iron sulphides 
come from a bacterial origin, $\mathrm{R}^{34} \mathrm{~S}$ is inferior to $\mathrm{R}^{34}$ Snatural. So, sulphur isotopic composition analyses could enable to distinguish the abiotic or biotic origin of the iron sulphides.

To compare the results issued from different publications, the isotopic fractionation in ${ }^{34} \mathrm{~S}$, called $\delta^{34} \mathrm{~S}$, refers $\mathrm{R}^{34} \mathrm{~S}$ to a standard sample, the Canon Diablo Troilite (CDT), the international sulphur isotope standard [40].

$$
\delta^{34} \mathrm{~S} \% \text { o }=\frac{R^{34} S(\text { sample })-R^{34} S(\text { standard })}{R^{34} S(\text { standard })} \times 1000
$$

The $834 \mathrm{~S}$ can also refer to the isotopic composition of sulphate in the environment [40]. Indeed in the major part of the studies related to the sulphur isotopic fractionation, ${ }^{32} \mathrm{~S}$ and ${ }^{34} \mathrm{~S}$ isotopes are determined on bulk solution or sediments samples by global mass spectrometry on solutions $[36,40$ 44]with the determination of $\delta^{34} \mathrm{~S}$ in sulphides relatively to sulphates of the medium. The $\delta^{3} \mathrm{~S}$ depletion values can be as high as $70 \%[40-42,45,46]$ for sulphides substrates when SRB a e involved.

Very few studies are reported in the literature on micrometric samples. One $f$ those conducted in the geoscience field by Lerouge et al [47], evidenced that, in the bottom par of the Callovo-Oxfordian argillite, $\delta^{34}$ S measured by microSIMS goes from $-38 \%$ to $-22 \%$ in the py ite suggesting its formation through the action of SRB. In the corrosion domain, the publications concerning the sulphur isotope fractionation are also rare. In the innovative study of Little et al. [48] the sulphur isotopic fractionation was measured by CF-IRMS (Continuous-Flow Isotopic Ratio Mass spectrometry) in corrosion products resulting from the activities of lphate-reducing bacteria within biofilms on metallic copper surfaces: ${ }^{32} \mathrm{~S}$ were accumulated in the corrosion products while ${ }^{34} \mathrm{~S}$ was concentrated in the culture medium due to fractionation. But thi innovative study in the corrosion field, was nevertheless carried out through the solely analyses of the corrosion solution, after the precipitation into $\mathrm{BaSO}_{4}$ of the sulphates, then combustion into $\mathrm{SO}_{2}$, and detection by global mass spectrometry. The global scale analysis can be then conducted when a representative sample of the medium can be collected. Nevertheless it is $\mathrm{n} t$ adapt $\mathrm{d}$ to solid samples of corrosion layers constituted of metallic sulphides precipitated locally at the micrometer scale [49].

Recent studies con erning the local determination of the sulphur isotopic fractionation in iron sulphides formed from abiotic or biotic way have been addressed [50,51]. These authors worked on solid samples and used a local secondary ion mass spectrometry technique, ToF-SIMS (Time-of-Flight Secondary I n Mass Spectrometry), to determine the origin of the iron sulphide compounds [50]. Two types of iron sulphides were considered in their study: chemical iron sulphides as commercial pyrite and iron sulphide obtained by thermal sulphidation of a metallic pure iron foil, and biological iron sulphides prepared by anaerobic immersion of iron in a sulphide solution produced by reduction of sulphate by SRB. The authors evidenced a lower ratio ${ }^{34} \mathrm{~S} /{ }^{32} \mathrm{~S}$ for the sulphide from biological origin than for those from chemical origin. This demonstrates the ability of the ToF-SIMS method to identify the biological origin of sulphide corrosion products on steel. However, they worked on laboratory 
samples that were not representative of corrosion layers formed in anoxic soils. Indeed these latter are generally constituted of a mix of iron sulphide and iron carbonate at the micrometric scale and this can decrease the precision of the ToF-SIMS measurement due to the overlap of the $\mathrm{O}_{2}{ }^{-}$and ${ }^{32} \mathrm{~S}^{-}$mass peaks. Moreover they worked on very short duration experiments ( 24 hours for the biotic samples) which don't authorize to determine the long term effect of the processes.

In specific cases, $\delta^{34} \mathrm{~S}$ values can be positive even if iron sulphides come from bacterial origin: it is the case of closed or semi-closed or confined systems corresponding to the absence of the renewal of the sulphate source. Indeed, in this absence of sulphate source renewal, the residual sulphates of the medium are depleted in ${ }^{32} \mathrm{~S}$ and the bacteria have to consume ${ }^{34} \mathrm{~S}$ for their sulphate reduction, which leads to an increase of $\delta^{34} \mathrm{~S}$. This observation was reported by Lerouge et al on iron sulphides located in the confined upper part of the Callovo-Oxfordian where the values of $\delta^{34} \mathrm{~S}$ ranges from $14 \%$ to $34.5 \%$ [47].

The aim of this paper is to develop a diagnosis method of the bio-origin of iron sulphides formed in iron CPLs thanks to the determination of the sulphur isotopic fractionation, by using the nanoSIMS technique, appropriate thanks to its excellent spatial and mass resolution, to the (sub)micrometer iron sulphide strips located in the CPLs. To tes the relevan e and the feasibility of the determination of iron sulphides origin by nanoSIMS, anoxic aqueous corrosion experiments in controlled conditions were carried out without or wit SRB to determine $\delta^{34} S$ values in each case and to compare to values reported in the literature. After the validation of nanoSIMS use on these model systems prepared in laboratory controlled condition the methodology was applied to a more representative samples of the nuclear waste storage in geological medium. For that an iron bar was corroded for 13 months in contact $w$ th clay and in presence of two bacterial strains, in an anoxic corrosion cell. In this paper, complementary techniques from micrometer to nanometer scales were used: SEM-EDS for the di tribution of iron sulphides in the CPLs, $\mu$ Raman for the crystalline nature of iron sulphides and nanoSIMS for the obtention of $\delta^{34} S$ which permits the determination of the formation origin of iron su phides.

\section{Materials and methods:}

\section{a. Corrosion in aqueous solutions}

For the laboratory anoxic corrosion experiments three set-ups were designed to corrode iron coupons in three different media with and without bacteria. The first one is fully abiotic and is named (A), the second one being fully biotic and named (B). The third one presents mixed conditions where the coupons were first corroded in presence of bacteria during two weeks. Then in a second step, the solution was filtered under anoxic conditions in order to eliminate the possible contamination of the 
bacterial lyse on longer duration of corrosion. Thus, the coupons are first corroded in biotic conditions. Then they were corroded in abiotic conditions in the solution containing the remaining sulphide produced by the bacteria during the first step. These samples are therefore designated by the denomination (B-A) for biotic-abiotic experiments. All these experiments were conducted using Goodfellow ${ }^{\circledR}$ iron coupons $(\mathrm{d}=10 \mathrm{~mm}$; thickness $=1 \mathrm{~mm}$; purity $=99.5 \%)$ in a $\mathrm{N}_{2} / \mathrm{CO}_{2}$ atmosphere (95\% / $5 \%$ ). All the elements required for these experiments were previously sterilised.

Two abiotic experiments ( $A_{1}$ and $\left.A_{2}\right)$ have been conducted at two durations (7 and 11 months). The experiments were conducted following the two stage protocol described by Sherar et al [52] to ensure the formation of iron sulphides of mackinawite type. So, two iron coupons per flask were first immersed into an anoxic carbonated solution without sulphides for one month. The composition of this medium was $25.2 \mathrm{~g} / \mathrm{L} \mathrm{NaHCO}_{3} ; 8.8 \mathrm{~g} / \mathrm{L} \mathrm{NaCl}$ and $21.3 \mathrm{~g} / \mathrm{L} \mathrm{Na}_{2} \mathrm{SO}_{4}$. Then, at the end of the first month, sodium disulphide salts $\left(\mathrm{Na}_{2} \mathrm{~S}\right)$ were added to the flasks in order to reach a sulphide concentration of $0.2 \mathrm{~g} / \mathrm{L}(2 \mathrm{mmol} / \mathrm{L})$. Then the flasks were stored at ambient temper ture during 6 and 10 months respectively, for a total duration experiment of 7 and 11 months (Figure 1).

For the biotic (B) experiments, two flasks containing the culture medium allowing an optimum growth of the bacterial strain were used [53]: a flask inoculated with the bact rial strain Desulfotomaculum aquiferis $\mathrm{Bs} 105^{\mathrm{T}}$ (= DSM 24088 ${ }^{\mathrm{T}}$ [ [53] and a control fla k without bacteria inoculation. The composition of this culture medium was $0.3 \mathrm{~g} / \mathrm{L} \mathrm{KH} 2 \mathrm{PO} 4 ; 03 \mathrm{~g} / \mathrm{L} \mathrm{K}_{2} \mathrm{HPO}_{4}$; $1.0 \mathrm{~g} / \mathrm{L} \mathrm{NH}{ }_{4} \mathrm{Cl} ; 1.0 \mathrm{~g} / \mathrm{L} \mathrm{NaCl} ; 3.0 \mathrm{~g} / \mathrm{L} \mathrm{Na}_{2} \mathrm{SO}_{4} ; 0.1 \mathrm{~g} / \mathrm{L} \mathrm{CaCl} 2 \mathrm{H}_{2} \mathrm{O} \quad 0.5 \mathrm{~g} / \mathrm{L} \mathrm{MgCl}_{2} .6 \mathrm{H} 2 \mathrm{O}$; $2.2 \mathrm{~g} / \mathrm{L}$ pyruvate; $10 \mathrm{~g} / \mathrm{L}$ dried yeast extract; $0.1 \% \mathrm{v}$ 1. solution of trace elements SL10; $0.05 \%$ resazurin. In each flask, two iron coupons were immersed. The flasks were stored at the optimum growth temperature $\left(35^{\circ} \mathrm{C}\right)$ for 1 week. The (B) experiment ended at the end of this first week (Figure 1).

In the case of the (B-A) exper ment the same solution than for biotic (B) experiments was prepared (see above). But in the (B-A) experiments the storage of the flasks at $35^{\circ} \mathrm{C}$ lasted one more week so that the biotic period lasts 2 weeks in total. This period corresponds to the end of the stationary phase of the bac rial growth. At this stage the medium has been filtrated in anoxic conditions in order to remove the bacteria from the solution. This filtration process was performed to limit the contamin tion $\mathrm{f}$ the medium by sulphur-containing species coming from the lyse of the bacterial cells Then to pursue the corrosion of the iron coupons on longer durations, the experiment was continued at $35^{\circ} \mathrm{C}$ in anoxic conditions to reach duration experiments ranging from 1 to 8 months (samples named of the $\left(\mathrm{B}-\mathrm{A}_{\mathrm{i}} ; \mathrm{i}=1\right.$ to 5 , see Figure 1$)$.

\section{b. Corrosion in clay}

The sample called "CBCC" results from a low-alloy steel corrosion tests in clay rock representative of the French High-Level Waste Disposal Concept and was briefly previously described [3]. This experiment was conducted during 13 months at $60{ }^{\circ} \mathrm{C}$. It consisted of a cylindrical 
percolation cell (see Figure 2) containing a vertical iron bar (diameter $3 \mathrm{~mm}$; height $1 \mathrm{~cm}$ ) inserted in a sample of Toarcian argillite of $42 \mathrm{~mm}$ diameter and $30 \mathrm{~mm}$ height [3]. The argillite was sampled at a depth of around $512 \mathrm{~m}$ in the IRSN (Institut de Radioprotection et de Sûreté Nucléaire) experimental station of Tournemire (Aveyron, France). At this altitude, the concentration of sulphates in the argillite porewater is estimated at $9.5 \mathrm{mmol} / \mathrm{L}[54,55]$. The clay is mainly composed of kaolinite, illite and smectite mixed to quartz and present about 2 to $5 \mathrm{wt} \%$ of pyrite [54]. It contains also about $4 \%$ maximum of water. For this experiment all the materials were previously sterilised and the set-up was realised in an anoxic glovebox. During the experiment, a flow of about $0.7 \mathrm{~mL} / \mathrm{day}$ of a synthetic solution was constantly injected from the bottom and evacuated at the top of the cell. The composition of this solution was chosen as close as possible to the pore water in equilibrium with the Tournemire clayey rock at $60{ }^{\circ} \mathrm{C}[54,56]: 0.395 \mathrm{~g} / \mathrm{L}\left(\mathrm{NH}_{4}\right)_{2} \mathrm{SO}_{4} ; 0.041 \mathrm{~g} / \mathrm{L} \mathrm{KH}_{2} \mathrm{PO}_{4} ; 0.303 \mathrm{~g} / \mathrm{L} \mathrm{NaHCO}_{3}$; $1.155 \mathrm{~g} / \mathrm{L} \mathrm{Na}_{2} \mathrm{SO}_{4} ; 0.081 \mathrm{~g} / \mathrm{L} \mathrm{NaCl} ; 0.054 \mathrm{~g} / \mathrm{L} \mathrm{KCl} ; 0.161 \mathrm{~g} / \mathrm{L} \mathrm{MgCl}_{2} .6 \mathrm{H}_{2} \mathrm{O}$. A layer of comp cted and calibrated iron powder $\left(\mathrm{d}_{\text {particule }} \leq 60 \mu \mathrm{m}, \mathrm{S}_{\text {specific }}=0.13+/-0.02 \mathrm{~m}^{2} / \mathrm{g}\right)$ was placed at the $\mathrm{b}$ thom of the cell in order to ensure an iron reservoir releasing iron ions in the solution during he exp riment. A difference in the concentration of the sulphate in the injected and evacuated solutions has been observed: this concentration is of $11.2 \mathrm{mmol} / \mathrm{L}$ in the injected one whereas is it is of $3.5 \mathrm{mmol} / \mathrm{L}$ in the released one [3].

Lastly, two bacterial strains were inoculated in the system the SRB Thermodesulfovibrio hydrogeniphilus $\mathrm{Hbr}^{\mathrm{T}}$ (= DSM 18151 ${ }^{\mathrm{T}}$ ) isolated from a hot spring water in Tunisia [57]and the ironreducing bacteria Thermotoga subterranea strain SL ${ }^{\mathrm{T}}\left(=\mathrm{DSM} 9912^{\mathrm{T}}\right)$ isolated from an oil reservoir in the east of the Paris basin [58]. Each of thes strains was firstly cultivated in the medium recommended by the strain bank DSMZ namely m dia 641 and 688 for T. hydrogeniphilus HBr5 and T. subterranean SL1 respectively. Then bo h bacterial strains were cultivated simultaneously in the synthetic solution representative of he To rnemire clay's pore water to ensure that they grow in this medium, poor in nutritive and ene geti elements but similar to the medium of the percolation cell. Finally they were inoculat $\mathrm{d}$ in the percolation cell at a rate of $4.10^{8}$ bacteria/mL.

\section{c. Sulphate olutions preparation for isotopic measurements}

Sulphate iso opi atios of the solutions were determined following the classical precipitation method developed in many papers (see for example Canfield 2001). Briefly, the sulphate was precipitated nto $\mathrm{BaSO}_{4}$ thanks to an addition of $\mathrm{BaCl}_{2} \cdot 2 \mathrm{H}_{2} \mathrm{O}$ salts to the sulphate solution. Then the isotopic ratio in $\mathrm{BaSO}_{4}$ is analysed by CF-IRMS (Continuous-Flow Isotopic Ratio Mass spectrometry). The sulphur isotopic composition of the sulphates in solution $\left(\mathrm{R}_{\exp }=\frac{\mathrm{I}^{34} S_{\exp }}{\mathrm{I}^{32} S_{\exp }}\right)$ was determined by CF-IRMS on $\mathrm{BaSO}_{4}$ extracts. An elementary analyser EA3000 (EuroVector ${ }^{\circledR}$ ) coupled with a mass spectrometer Horizon ( $\mathrm{Nu}$ Instruments $\left.{ }^{\circledR}\right)$ was used. Calibration was realised thanks to the international sulphur isotopic standard CDT (Cañon Diablo Troilite) [44,59]. 


\section{d. Sample preparation on transverse section}

Half of the iron coupons of the (B), (B-A), and (A) experiments were dedicated to surface analyses whereas the other half of the coupons as well as the CBCC sample were analysed on crosssection. For this purpose, these samples were embedded in an epoxy resin (Specifix-20, Struers ${ }^{\circledR}$ ) and cut with a diamond saw. They were then ground with SiC paper (grad 320-4000) and diamond polished under ethanol down to $1 \mu \mathrm{m}$. The whole preparation process was carried out in an anoxic glove box $\left(\mathrm{O}_{2}\right.$ concentration $\left.<100 \mathrm{ppm}\right)$ whose relative humidity was controlled by silica gel to avoid the transformation of the anoxic phases.

\section{e. Analytical techniques}

For the sample characterisation, the following methodology was followed: co pon were first analysed by Scanning Electron Microscope (SEM) coupled to Energy Dispersive Spectroscopy (EDS) and Raman spectroscopy in order to determine respectively the chemical composition and the crystalline structure of the phases precipitated during the laboratory experiments. These techniques were also performed on the transverse sections of the coupons and of the CBCC sample in order to locate these phases in the corrosion layer prior to the isotopic analyses. Thus in order to study the sulphur isotopic composition of these thin iron sulphide laye $s$, the high spatial resolution of the NanoSIMS technique was necessary. Another reason to $\mathrm{u}$ e this technique is the presence of iron carbonates mixed with the sulphides at the submicrometric scale. Carbonates are oxygenated phases, and a high mass resolution $(\mathrm{m} / \Delta \mathrm{m}$ of 10000$)$ is required to separate the ${ }^{32} \mathrm{~S}$ from the ${ }^{16} \mathrm{O}_{2}$ mass contribution (see section 2.5.3 for the acqui ition strategy).

\section{i. Field-Emission Scanning Electron Microscopy (FESEM) and EDS}

FESEM images in secondary electron mode and EDS spectra were obtained with a microscope JEOL JSM-7001F. An acceleration voltage of $15 \mathrm{kV}$ was used. The location of the phases, especially the sulphur-containing compounds, was determined by EDS thanks to a silicon drift detector. The surface of the samples as coated with a carbon layer before analysis to prevent sample charging.

\section{ii. $\mu$ Raman spectroscopy}

$\mu$ Raman measurements were carried out on the surface of the (A), (B) and (B-A) iron coupons and on the cross-section of the sample CBCC at room temperature via an Invia Reflex ${ }^{\circledR}$ spectrometer of Renishaw. Spectra were acquired through the glass window of an anoxic cell [60]enabling analyses of the samples in anoxic conditions. The Raman spectrum of the glass is presented in Figure 3. Spectra were acquired with an excitation wavelength of $532 \mathrm{~nm}$. The laser power was filtered down to $0.1 \mathrm{~mW}$ and the spectra were recorded with a resolution of $2 \mathrm{~cm}^{-1}$. The laser beam diameter was of $1 \mu \mathrm{m}$. The 
spectrometer calibration was obtained from a silicon crystal which main peak is at $520.5 \mathrm{~cm}^{-1}$. The acquisition time for each spectrum was between 30 and 120 seconds. The acquisition and treatment of the spectra were obtained with the software Wire $3.4^{\circledR}$. Because of high fluorescence signal, the baseline was removed for all the Raman spectra.

In this study, five main corrosion products are expected: siderite $\left(\mathrm{Fe}^{\mathrm{II}} \mathrm{CO}_{3}\right)$, greigite $\left(\mathrm{Fe}^{\mathrm{II}} \mathrm{Fe}_{2}{ }_{2} \mathrm{~S}_{4}\right)$, nanocrystalline mackinawite $\left(\mathrm{Fe}^{\mathrm{II}} \mathrm{S}\right)$, crystalline mackinawite $\left(\mathrm{Fe}^{\mathrm{II}} \mathrm{S}\right)$ and $\mathrm{Fe}^{\mathrm{III}}$-containing mackinawite (Fe $\left.{ }^{\mathrm{IIIIII}} \mathrm{S}\right)$. The detailed attributions of the Raman bands to liaison oscillation modes in iron sulphide phases have previously been detailed [49].

\section{iii. nanoSIMS}

The S-isotopic composition analyses of the iron sulphide were conducted on the nanoSIMS N50 (CAMECA $\left.{ }^{\circledR}\right)$. The analyses were carried out on polished resin-embedded cross-sections coated with a golden layer $(\sim 20 \mathrm{~nm})$ to prevent charge accumulation. The area of interest was $\mathrm{f}$ rstly p esputtered for $\sim 30$ minutes to remove the gold coating from the area of interest, clean the surface and reach the steady-state sputtering equilibrium. Presputtering was realised with high-current (18 pA) primary $\mathrm{Cs}^{+}$ beam using D1-1 aperture diaphragm $\mathrm{Cs}^{+}$. After this preparation the aperture diaphragm was then set at $150 \mu \mathrm{m}(\mathrm{D} 1-4)$ to reduce the current to about $1 \mathrm{pA}$ for the analysis. This allowed reaching a measured beam size of about $70 \mathrm{~nm}$.

During the analysis the secondary ions ${ }^{32} \mathrm{~S}, \mathrm{~S}^{-}$, and ${ }^{16} \mathrm{O}^{-}$were detected simultaneously to abrasion in a multicollection mode using three onsecutive electron multipliers. Analytical conditions (ES3, AS3, EnS-20\%) were set to achieve high mass resolution, e.g. of about 10,000 (Cameca definition) on ${ }^{32} \mathrm{~S}$.

The isotopic fractionation in $34 \mathrm{~S}$, call $\mathrm{d} \delta^{3} \mathrm{~S}$, refers $\mathrm{R}^{34} \mathrm{~S}$ to a standard sample, the Canon Diablo Troilite (CDT), the international s lph r i otope standard, or to the sulphate of the environment. For samples extracted from natura systems, not only the sulphur isotopic fractionation resulting from the corrosion processes but als the sulphur isotopic fractionation accumulated by the sulphur species before the beginning of co rosion processes contribute to the value of $\delta^{34}$ Ssulphides-CDT. On the contrary, the value of $\delta^{34}$ Ssulphides-sulphates only quantifies the sulphur isotopic fractionation occurrin during the corrosion processes. So, the use of $\delta^{34}$ Ssulphides-sulphates is more adapted to corrosion studies. Therefore, only the values of $\delta^{34}$ Ssulphides-sulphates are discussed in this article.

For standards and references, areas of $5 \times 5 \mu \mathrm{m}^{2}$ were presputtered and central zones of $3 \times 3 \mu \mathrm{m}^{2}, 64 \times 64$ pixels, were analysed. For the samples, a $12 \times 12 \mu \mathrm{m}^{2}$ area was presputtered, and $9 \times 9 \mu \mathrm{m}^{2}$ zones, $256 \times 256$ pixels, were analyzed. Each image is a stack of 26 to 170 scans. The experimental ${ }^{34} \mathrm{~S}^{-} /{ }^{32} \mathrm{~S}$ ratios are deduced from the stack image processing realized with the L'IMAGE software package developed by L. Nittler (Carnegie Institution of Washington) (see Figure 4). 
Due to the high ionization efficiency of S the QSA (quasi-simultaneous arrival) effect was taken into account for the correction of the obtained isotopic ratios $[61,62]$. To quantify the QSA effect and to correct it was proceeded as follows: the entrance slit was set to $30 \mu \mathrm{m}$ (ES3) and the other aperture and energy slit widths were varied. This results in the measurement of the secondary ion count rates which varies from $5,000 \mathrm{cps}$ to $330,000 \mathrm{cps}$ for ${ }^{32} \mathrm{~S}$ depending on the local matrix and topography. In this study the mass fractionation due to QSA effect ranges from $0.6 \%$ ( $\mathrm{K}_{\text {cor }}=0.001, \mathrm{I}^{32} \mathrm{~S}=5300 \mathrm{cps}$, B- $\mathrm{A}_{1}$ sample) to $39 \%\left(\mathrm{~K}_{\text {cor }}=0.045, \mathrm{I}^{32} \mathrm{~S}=330000 \mathrm{cps}, \mathrm{CBCC}\right.$ sample point 3$)$. Consequently, the QSA effect was corrected based on methods previously detailed in the literature $[63,64]$. In our case, three different sulphide phases matrix have been used to correct the ${ }^{34} \mathrm{~S} /{ }^{32} \mathrm{~S}$ ratios from the QSA: the CDT [44,59], a hydrothermal pyrite (PLV) and a greigite $\mathrm{Fe}_{3} \mathrm{~S}_{4}$ reference. Pure greigite mineral was unavailable and the synthesis of homogeneous greigite samples was very difficult because of ts high reactivity to oxygen. That's why an archaeological nail (RH1202) containing pure greigite ar as located by Raman spectroscopy $\left(\mathrm{S} \approx 2000 \mu \mathrm{m}^{2}\right)$ and coming from the terrestrial site of Rådhuspladsen (Copenhagen, Denmark) [49] was used as greigite matrix for the QSA correction

\section{Results}

\section{a. Corrosion in aqueous solution}

The surfaces of the (A), (B-A) and (B) coupons were first analysed in the anoxic cell by $\mu$-Raman spectroscopy. Examples of spectra obtained for each kind of experiment are presented on Figure 5. In all cases a mix of crystalline mackinawite (FeS, main peak at $\left.294-297 \mathrm{~cm}^{-1}\right)$, and greigite $\left(\mathrm{Fe}_{3} \mathrm{~S}_{4}\right.$, peak at $340-370 \mathrm{~cm}^{-1}$ ), is identified [49]. On the (A) coupon, nanocrystalline mackinawite (main peak at $\left.280 \mathrm{~cm}^{-1}\right)$ and iron carbonates $\left(\mathrm{FeCO}_{3}\right.$, sharp band at $\left.1083 \mathrm{~cm}^{-1}\right)$ are also observed [49]. Thus, similar iron sulphides are identified in both biotic nd abiotic systems.

FESEM-EDS analyses realised on ross-sections enabled to precisely locate the sulphurcontaining phases. An example of the iron and sulphur EDS maps obtained on a (A) coupon is presented on Figure 6. It sh ws that the sulphur layer presents a thickness of few micrometers. The EDS maps obtained on the cross-section of other (A), (B-A) or (B) coupons led to the same observation.

The sulp ur isotopic fractionation $\delta^{34} S$ of the sulphate powders used for the preparation of the solutions was measured by CF-IRMS relative to the CDT standard. The $\delta^{34}$ sulphates-CDT $_{\text {obtained is of }}$ $0.7 \pm 0.3 \%$. As it was not possible to measure the $\delta^{34} \mathrm{~S}$ of $\mathrm{Na}_{2} \mathrm{~S}$ due to the deliquescent state of the compound and considering that both sulphur containing compounds, were acquired from the same supplier, the hypothesis that the $\delta^{34} \mathrm{~S}_{\text {sulphides-CDT }}$ is close for both $\mathrm{Na}_{2} \mathrm{SO}_{4}$ and $\mathrm{Na}_{2} \mathrm{~S}$ compounds is reasonable. So in the following the $\delta^{34} \mathrm{~S}_{\text {sulphides-sulphates fractionations measured on the experimental }}$ 
samples are expressed relative to the $\delta^{34} S_{\text {sulphates-CDT }}$ of $0.7 \pm 0.3 \%$.

The sulphur isotopic fractionation measured on the sulphides for each coupon were calculated from the measured and corrected ratio ${ }^{34} \mathrm{~S} /{ }^{32} \mathrm{~S}$ (see methodology section) and are displayed in Table 1 relative to the CDT ( $\left.\delta^{34} S_{\text {sulphides-CDT }}\right)$ and relative to the sulphates of the experimental solution $\left(\delta^{34} \mathrm{~S}_{\text {sulphides-sulphates }}\right)$.

For the abiotic coupons (A), $\delta^{34} \mathrm{~S}_{\text {sulphides-sulphates }}$ ranged between $4.8 \pm 6.2 \%$ and $14.5 \pm 5.7 \%$, namely between $-1.4 \%$ and $20.2 \%$ when taking the error into account. On the biotic (B) coupon, $\delta^{34} \mathrm{~S}_{\text {sulphides-sulphates }}$ are very close and yield from $-24.7 \pm 5.2 \%$ to $-25.5 \pm 6.4 \%$, namely between $31.9 \%$ and $-19.5 \%$ when taking the error into account. Finally, for the biotic and then abioti (B-A) coupons $\delta^{34} \mathrm{~S}_{\text {sulphides-sulphates }}$ ranges from $-29.6 \pm 6.5 \%$ to $-7.5 \pm 6.2 \%$, namely between $36.1 \%$ and $1.3 \%$ when error is included.

\section{b. Corrosion in clay}

Previous observations have shown that the main corrosion profile obse ved is constituted of siderite and chukanovite characteristic of corrosion in anoxic conditions in presence of a carbonated solution [3]. But locally the observation on transverse section of he CBCC sample by optical microscopy reveals the presence of a brilliant strip of several micrometers to several tens of micrometers thick. It is located in contact with the m tallic matrix (Figure 7) and is mainly composed of sulphur and iron: $29.4 \mathrm{w} \%$ and $54.2 \mathrm{w} \%$ respectively (Figure 7 - red point). The $\mu$-Raman spectrum obtained on this strip (Figure 8) present a peak at $292 \mathrm{~cm}^{-1}$ characteristic of the crystalline mackinawite and a large band between 335 nd $365 \mathrm{~cm}^{-1}$ that could be attributed to greigite 53 [49]. Thus, this strip is composed of a mi of iron sulphides similar to those observed in aqueous solution.

In this set-up the $\delta^{34} S_{\text {sulphate-CD }}$ of he sulphate of the solution injected in the cell was not measured but as the compound was from the same supplier as the one used for the coupons experiment the same $\delta^{34} S_{\text {sulphates-CDT }}$ value of $0.7 \pm 0.3 \%$ was taken as a reference for the calculation of the $\delta^{34} \mathrm{~S}_{\text {sulphides-sulphates }}$ in this ex riment. Three analyses were realised by nanoSIMS on the iron sulphides detected within the corrosion layer (Figure 7 and Figure 9). The values of $\delta^{34} S_{\text {sulphides-sulphates }}$ obtained on this s mple are comprised between $-4.0 \pm 5.0 \%$ and $-3.1 \pm 4.7 \%$ namely between $-9 \%$ and $+1.6 \%$ when error is included (Table 2).

\section{Discussion}

The graph of Figure 9 gathers the values of $\delta^{34} S_{\text {sulphides-sulphates }}$ of all the samples studied in this paper. The results are commented and discussed in the paragraphs below. 


\section{a. Corrosion in aqueous solution}

For each experiment in aqueous solution, the iron sulphides formed on the surface of the iron coupons could result from a single process: either abiotic (A) or biotic (B and B-A). In the following paragraphs, the possibility to determine the origin from the sulphur fractionation $\delta^{34} \mathrm{~S}$ measurement will be discussed.

For the (A) experiments, two measurements were obtained after 7 months and four after 11 months of corrosion. The average value is of 12.6 for 7 months and 9.5 for 11 months. Thus values vary inside each sample but they remain close for the two durations of the experiment. The range of sulphur isotopic fractionation obtained $(\Delta=19 \%)$ is similar to what is given in the literature ( $\Delta \approx 20 \%$ ) for iron sulphides collected from an abiotic reaction [65]. Yet, the values obtained in this work are slightly superior to what was expected for abiotic sulphides, namely a range between -10 and $+10 \%$ even since the reference used is the source of sulphates with a measured $\delta^{34} \mathrm{~S}_{\text {sulp ates-CD }}$ value of $0.7 \pm 0.3 \%$. This could be explained by the slight oxidation of the (nano)-crystallin ma kinawite into greigite when experiments are stopped, samples are dried in the glovebox and transported in the raman cell. Indeed, sulphur isotopic fractionations up to $+10 \%$ during inorganic oxidation processes have been previously reported in the literature when sulphur oxidation degr e vari s. For example, Oana $e t$ al. 70 [66] conducted laboratory experiments and have shown that disproportionation reaction of sulphurous acid $\left(\mathrm{H}_{2} \mathrm{~S}^{+\mathrm{IV}} \mathrm{O}_{3}\right)$ into sulphuric acid $\left(\mathrm{H}_{2} \mathrm{~S}^{+\mathrm{VI}} \mathrm{O}_{4}\right)$ and sulphur $\left(\mathrm{S}^{0}\right)$ induced an enrichment of up to $+10.4 \%$ in ${ }^{34} \mathrm{~S}$ for the $\mathrm{H}_{2} \mathrm{~S}^{+\mathrm{VI}} \mathrm{O}_{4}$ compound and a deple ion in ${ }^{34} \mathrm{~S}$ of $-13.5 \%$ or the $\mathrm{S}^{0}$.

Thus, the slight oxidation of the iron sulphides produc d during the abiotic experiments could explain the slight enrichment in ${ }^{34} \mathrm{~S}$ while no fractionation was expected since the sulphides are from inorganic origin.

Concerning the variation of the duration of the abiotic experiments, no influence of this parameter has been evidenced on the sulphur i otopic fractionation values obtained. Thus for the abiotic experiments it can be concluded th $t$ th ulphur isotopic fractionation values obtained by nanoSIMS are close to $0 \%$ and are theref re consistent with the abiotic origin of the iron sulphides.

For the biotic expe ime ts, two protocols were applied. In the first one, called the biotic (B) experiments one, $\mathrm{c}$ upons ere exposed no more than one week to the direct contact with the solution containing bacteria For the second protocol called biotic-abiotic (B-A), durations of experiments were extended from one week to 8 months but coupons were exposed to the filtered solution obtained from the biotic experiments. This protocol was chosen to reduce the impact of the bacterial lyse which could induce the presence of dead cells inside the corrosion layers formed and disrupt the final fractionation measurements due to the presence of intra-cellular sulphur.

First, prior to the comment of the results, we may assume that the same phenomenon of oxidation of the iron sulphides from abiotic origin can impact the biotic experiments and shifts their fractionation towards higher values as well.

Apart of that, it has been observed that results are very homogeneous for the biotic coupons, 
between, $-24.7 \%$ and $-25.5 \%$ for the $\delta^{34} S_{\text {sulphides-sulphates. }}$. Moreover while considering the first short duration of one month for the $\mathrm{B}-\mathrm{A}_{1}$ coupon, the $\delta^{34} \mathrm{~S}_{\text {sulphides-sulphates }}$ is very close as well as the biotic one at $-29.6 \%$. In these experiments (B and $\mathrm{B}-\mathrm{A}_{1}$ ) the iron sulphides are depleted in ${ }^{34} \mathrm{~S}$ relative to the sulphates which shows that the results obtained by nanoSIMS are consistent with the fact that the source of sulphides in this system was the bacterial metabolism.

Concerning the $\delta^{34} \mathrm{~S}_{\text {sulphides-sulphates }}$ values measured for the B- $\mathrm{A}_{2}$ to $\mathrm{B}-\mathrm{A}_{5}$ coupons corroded on periods from 2 to 8 months the $\delta^{34} S$ results obtained are more dispersed. They extend from $-28.1 \%$ to 9.7 for the highest. It can be first noted that there is no correlation of these variations with the duration of the experiments. Moreover the slight oxidation of the sulphur inside the sulphide compounds can't explain such strong variations as discussed previously.

As obtained for the biotic coupons, the negative values obtained on the (B-A) coupon tend to show that the iron sulphides are depleted in ${ }^{34} \mathrm{~S}$ and therefore that they would be ue to biotic origin. Nevertheless the inhomogeneity of the results compared to the strictly biotic preparation raise questions about the influence of the long term duration process. In the iterature, the case of an evolution of the $\delta^{34} S$ fractionation towards higher value has been observed in geological environments [44,47]. It is explained by the confinement occurring in such environments due to the sedimentation phenomenon. Thus, in sediments the renewal of a solution can be weak because controlled by diffusion processes only. The SRB metabolism in the e co ditions adapts to the available sulphate. Thus if the concentration of ${ }^{32} \mathrm{SO}_{4}{ }^{2-}$ ions decreas $\mathrm{s}$ due to their consumption by the biological processes, bacteria will increase their co sumption of ${ }^{34} \mathrm{SO}_{4}{ }^{2-}$ ions. Therefore the fractionation $\delta^{34} \mathrm{~S}$ of the sulphide produced by the bacteria etabolism will increase according to a Rayleigh modelling as it has been shown in the literature [47].

In some cases, when a long-term confinement occurs (at a geological timescale), positive $\delta^{34} S$ can be measured. But in the B A experiments, the conditions of a decrease of the ${ }^{32} \mathrm{SO}_{4}{ }^{2-}$ ions is not relevant because the bacteria are suppressed from the solution before starting the second step of these experiments (namely the abiotic step). The solution of the experiment contains sulphide ions produced by bacterial process $s$ at the beginning of the B-A experiments with a certain $\delta^{34} S$ value probably close to the one measured on the biotic coupons. That is why even for the short term experiment B-A1 of one week, th sulphur isotope fractionation $\delta^{34} S$ of the sulphides precipitated in the corrosion layer are close to the biotic experiments. That conducts to the precipitation of depleted sulphide on the corroded coupons (between -29.6 and -24.7\%). But when the duration of exposure of the coupons to the biotic sulphide in a sealed beaker in anoxic conditions is longer, this provokes an increase of $\delta^{34} \mathrm{~S}$. Thus in this experiment, the increase of the $\delta^{34} \mathrm{~S}$ can be explained by the production of sulphide from the sulphate containing solution maintained in anoxic conditions. As the corrosion processes in anoxic 
conditions lead to the production of $\mathrm{H}_{2}$, the solution is maintained anoxic. One can assume that the equilibrium in solution between sulphate and sulphide is shifted to the sulphide side in reducing conditions. This induces a production of sulphide ions that present $\delta^{34} \mathrm{~S}$ close to the one of the original sulphate used to prepare the solution $\left(\delta^{34} S_{\text {sulphates-CDT }}\right.$ of $0.7 \pm 0.3 \%$ ). Therefore the precipitation of sulphide phases on the corroded coupons integrate a mix of depleted and less depleted $\delta^{34} \mathrm{~S}$ sulphides so that the results obtained presents more extended and higher $\delta^{34} \mathrm{~S}$ values on the $\mathrm{B}-\mathrm{A}_{2}$ to $\mathrm{B}-\mathrm{A}_{5}$ coupons.

\section{b. Corrosion in clay}

Contrary to the iron coupons corroded in aqueous solution, the iron sulphides in the sample CBCC could result from two possible processes: a biotic and an abiotic one. Indeed, abiotic iron sulp ides could result either from the production of anoxic sulphide during the experiments or from the dissolution and re-precipitation of the pyrite contained in the argillite. Besides bioti iron sulphides could result from the SRB strain, Thermodesulfovibrio hydrogeniphillus [57] that was inoculated in the percolation cell in presence of a renewed solution containing sulphate.

To conclude on the biotic or abiotic origin of the iron sulphides observed in this sample, the methodology previously tested on the iron coupons corroded in controlled conditions was applied. Thus, the sulphur isotopic composition of the iron sulphides was ompared with the one of the sulphates of the surrounding medium. These sulphates are composed of sulphates from the synthetic solution injected in the cell and sulphates from the natura porewater contained in the cylindrical Toarcian argillite sample. Their respective quantities have been therefore estimated to evaluate their influence on the precipitation of sulphides. The quantity of sulphates provided by the Toarcian argillite sample is estimated at $43 \mu \mathrm{mol}$. This is calc lated by taking into account the volume of the argillite sample (42 $\mathrm{mm}$ diameter and $30 \mathrm{~mm}$ height) [3], its density $\left(2700 \mathrm{~kg} / \mathrm{m}^{3}\right)$, a percentage by mass of water of $4 \%$ [55], and a concentra ion $\mathrm{f}$ sulphates in the porewater of $9.5 \mathrm{mmol} / \mathrm{L}$ [54]. The quantity of sulphates provided by the synthetic solution retained inside the cell is estimated to be $2200 \mu \mathrm{mol}$. This is calculated thanks to the following experiment parameters: the injection solution flux $(0.7 \mathrm{~mL} /$ day) [3], $\mathrm{t}$ e diffe ence between the sulphate concentration in the synthetic solution injected in the cell $(11.2 \mathrm{mmol} / \mathrm{L})$ and the sulphate concentration in the solution released from the cell $(3.5 \mathrm{~mm} \mathrm{1/L)} \mathrm{[3].} \mathrm{This} \mathrm{demonstrates} \mathrm{that} \mathrm{the} \mathrm{porewater} \mathrm{of} \mathrm{the} \mathrm{argillite} \mathrm{clay} \mathrm{sample} \mathrm{only} \mathrm{contributes} \mathrm{up}$ to $2 \%$ of the otal sulphates. Consequently, as a first approximation, the sulphur isotopic fraction of the sulphides is calculated relative to the sulphur isotopic fractionation of the sulphate powders used to make the synthetic poral solution. The sulphur isotopic fractionation of this sulphate powder relative to the international standard CDT is $-0.7 \pm 0.3 \%$. Three analyses were realised on the iron sulphides within the corrosion layer (Figure 7 and Figure 9). The $\delta^{34} S_{\text {sulphides-sulphates }}$ measurements are close regardless of the area analysed: between $-4.0 \pm 5.0 \%$ and $-3.1 \pm 4.7 \%$. These negative values support the hypothesis of a biotic origin of the iron sulphides formed in the sample CBCC. However, the iron 
sulphides are only slightly depleted in ${ }^{34} \mathrm{~S}$ relative to the sulphate's source in the medium compared to the isotopic fractionations obtained on the coupons from the (B) and (B-A) solution experiments.

The $\delta^{34} \mathrm{~S}$ of the precipitated sulphides measured on this sample result from a complex set of parameters occurring during the whole duration of the experiment. The slight negative $\delta^{34} S$ values proceed from the processes occurred during the 13 months it lasted. But the period of the precipitation of the sulphide is not known. It could have occurred during the first period of the experiment. In this case, as measured on the coupons they should have been clearly depleted in ${ }^{34} \mathrm{~S}$ as observed on the $\mathrm{B}$ or $\mathrm{B}-\mathrm{A}_{1}$ coupons. As it is not the case, these sulphides may have precipitated later during the corrosion process. The same hypothesis than for the biotic-abiotic experiments can be made to explain the slight depleted fractionation obtained on CBCC experiment. In the bottom of the cell of the CBCC experiment, iron powder was filled up in order to ensure a low redox and the maintenance of noxic conditions throughout the experiment. When the cell was dismantled, iron powder was entire $y$ corroded and a mix of magnetite and siderite phases were identified [67]. It shows that the cell could have been under a $\mathrm{H}_{2}$ atmosphere during a long period of the experiment. Thus the redu tion of the sulphate ions into sulphide ones was occurring during the experiment. The pr cipitated iron sulphides observed on the iron bar have probably precipitated from these sulphide ions that had a $\delta^{34} \mathrm{~S}$ fractionation very close to the one of the original synthetic sulphate solu ion The slight depletion could be explained by a mix of these anoxic sulphides with a $\delta^{34} \mathrm{~S}$ close to 0 with few sulphides produced through bacterial metabolism although when taking the error bar into account this hypothesis can't be fully verified.

However several other explanations can conduct to understand the slight depletion of $\delta^{34} \mathrm{~S}$ in the observed sulphides. According to the litterature, the difference of sulphur isotopic fractionation can be explained by a difference of medium (state, temperature and composition) [46], by a difference of oxydation state of the sulphur compounds [66]and/or by the use of a different SRB strain [68] and various growing media [40]. Besides, he contribution of the sulphates from the porewater of the argillite through bacterial proc sses could have led to the precipitation of these iron sulphides. The sulphur isotopic fractionati $\mathrm{n}$ of sulphates from the argillite porewater ranges indeed from 0.6 to $45.6 \%$ relative to the CDT due to the long-term confinement of the argilite during the sedimentation processes [56]whe eas the sulphur isotopic fractionation of the commercial sulphate powder measured by CF-IRMS $\mathrm{i}$ of $-0.7 \%$ relative to the CDT. If the sulphides are the result of a bacterial transformati $n$ of the sulphate of the argilite alone enriched in ${ }^{34} \mathrm{~S}$, the $\delta^{34} \mathrm{~S}$ of the precipitate sulphide can be less depleted and could then approach values close to 0 as it was measured. The sulphides could be therefore from a biotic origin. This hypothesis is nevertheless not very comforted by the fact that the sulphates from the argillite are 50 times less concentrated than the one of the solution. As bacteria metabolize preferentially the ${ }^{32} \mathrm{SO}_{4}{ }^{2-}$ ions, the precipitated sulphides should be then depleted in ${ }^{34} \mathrm{~S}$ in this case. 
Another hypothesis connected to the medium could support an abiotic origin of the sulphide precipitated since the pyrites from the argillite could themselves present a sulphur isotopic fractionation of around $-4 \%$ relative to the source of sulphates. Unfortunately, no isotopic analysis has been done on the pyrites of the argillite. Nevertheless, the only case where the iron sulphides could result from abiotic processes is if $\mathrm{pH}$ and redox conditions are suitable for pyrite dissolution. Yet, the measured $\mathrm{pH}$ is 7.4 and the redox potentiel obtained by modeling ranges from -200 to $-700 \mathrm{mV} / \mathrm{ESH}$ [69]depending on the progress of the experiment. These conditions are unfavorable to pyrite dissolution $[28,70]$.

To conclude on this corrosion experiment in presence of argilite and bacteria, it seems that the local precipitation of iron sulphide on the corroded bar could be related both to the inte venti $\mathrm{n}$ of a bacterial metabolism and to the anoxic conditions of the experiment. These phenom na could respectively explain the negative $\delta^{34} \mathrm{~S}$ fractionation obtained; and that this deplet on in ${ }^{3} \mathrm{~S}$ is slight. The higher medium temperature, the different bacterial strain and growing $\mathrm{m}$ dia used may also explain the slight depletion in ${ }^{34} \mathrm{~S}$ observed relative to those obtained is the $\mathrm{B}$ and $\mathrm{B}-\mathrm{A}_{1}$ experiments. These observations are nevertheless very instructive on the possibility to determine the biotic or abiotic origin of iron sulphides. It shows that an application to fi ld measurement must integrate a good knowledge of the corrosive conditions before concluding only from the $\delta^{34} \mathrm{~S}$ values measured.

\section{Conclusion}

It was successfully demonstrated in this paper that sulphur isotopic analyses by nanoSIMS is adapted to determine the biotic or abiotic origin of localized (sub)micrometric iron sulphides in the corrosion product layers of iron coupon. The methodology developed in this study has been tested in the case of iron coupons corroded in solution in abiotic and biotic solutions to demonstrate the feasibility of the diagnosis me hod. Then it has been applied to an iron bar corroded in a laboratory cell in a clay environment o test it in a more applied experiment. The $\delta^{34} \mathrm{~S}_{\text {sulphides-sulphates }}$ values obtained for iron s lphides formed through a bacterial pathway in fully biotic conditions, range between -25.5 and $24.7 \%$ and denote a depletion of ${ }^{34} \mathrm{~S}$ content in the precipitated iron sulphides. On the contr ry, $\mathrm{t}$ e $\delta^{34} \mathrm{~S}_{\text {sulphides-sulphates }}$ values obtained on iron sulphides formed by an abiotic pathway are close to $0 \%$ which means that they are not depleted neither enriched in ${ }^{34} \mathrm{~S}$. Thus, the values obtained for both biotic and abiotic experiments are consistent with what has been previously stated in the literature. To apprehend better the phenomenon occurring on longer periods, a mixed experiment combining a short biotic period to an abiotic one in presence of the filtered biotic solution to avoid the bacterial lyse have been also conducted. It shows that after a longer period in absence of living

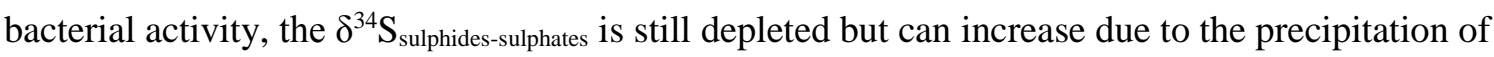
abiotic sulphides generated through the equilibrium reaction between the sulphate and the sulphide of 
the medium in anoxic reducing conditions inducing the formation of sulphides ions not depleted in ${ }^{34} \mathrm{~S}$. This process can be accelerated at the vicinity of the corroding piece of iron that produces $\mathrm{H}_{2}$ during the corrosion process.

To conclude, the method developed in this study is especially useful to identify a biotic iron sulphide formation process when the iron sulphides are present as (sub)micrometric layers and/or when the surrounding dissolved sulphates can't be sampled to determine their sulphur isotopic ratio as it is usually performed in geological environments. Furthermore, the study of the spatial distribution of the sulphur isotopic fractionation in forthcoming works could allow to distinguish the successive steps involved in the formation of the corrosion facies observed in anoxic conditions thanks to the coupling of the characterization of the origin of the sulphur phases (nanoSIMS) and the nature of the sulphur compounds mixed at the submicrometric scale.

\section{$\underline{\text { Author statement }}$}

The authors' individual contributions are detailed below:

Writing: S. Grousset, D. Neff, F. Mercier-Bion

Data curation: S. Grousset, S. Mostefaoui

Conceptualization: S. Grousset, D. Neff, F. Mercier Bion

Formal analysis: S. Grousset, S. Mostefaoui

Funding acquisition: V. Deydier, D. Crusset, A. Dauzeres, D. Neff, P. Dillmann

Investigation: S. Grousset, D. Neff, F. Mercier-Bion, S. Mostefaoui, L. Urios

Methodology: S. Grousset, D Neff, F Mercier-Bion, S. Mostefaoui, L. Urios

Project administration: D. Ne f, F Mercier-Bion, P. Dillmann, V. Deydier, D. Crusset, A. Dauzeres

Resources: L. Urios D. N ff, P. Dillmann,Y. Linard, V. Deydier, D. Crusset, A. Dauzeres

Supervision D. Neff, F. Mercier-Bion, P. Dillmann

Validati n: D Neff, F. Mercier-Bion, P. Dillmann, V. Deydier, D. Crusset, A. Dauzeres, Y. Linard

Visualization: S. Grousset, D. Neff, F. Mercier-Bion

Writing - original draft: S. Grousset, D. Neff, F. Mercier-Bion

Writing - review and editing: S. Grousset, D. Neff, F. Mercier-Bion 


\section{Data availability}

The raw/processed data required to reproduce these findings cannot be shared at this time due to legal or ethical reasons.

\section{Acknowledgements}

We are grateful to the IRSN (Institut de Radioprotection et de Sûreté Nucléaire) and Andra (Agence nationale pour la gestion des déchets radioactifs) for the scientific and financial support, as well as to PLATIN' (PLATeau d'Isotopie de Normandie, France) core facility and MNHN (Museum National d'Histoire Naturelle, Paris, France) for the sulphur isotopic analysis. We want to thank $\mathrm{D}^{\mathrm{r}}$ Ranchou-Peyruse for providing the bacterial strain Desulfotomaculum aquiferis $\mathrm{Bs} 105^{\mathrm{T}}$. 


\section{References}

[1] B. James, A. Hudgins, Chapter 1 - Failure analysis of oil and gas transmission pipelines A2 Aliofkhazraei, Abdel Salam Hamdy MakhloufMahmood, in: Handb. Mater. Fail. Anal. with Case Stud. from Oil Gas Ind., Butterworth-Heinemann, 2016: pp. 1-38.

[2] V.S. Sastri, 5 - Corrosion processes and the use of corrosion inhibitors in managing corrosion in underground pipelines A2 - Orazem, Mark E., in: Undergr. Pipeline Corros., Woodhead Publishing, 2014: pp. 127-165.

[3] C. Chautard, J.E. Lartigue, M. Libert, F. Marsal, L. De Windt, An Integrated Experiment Coupling Iron/Argillite Interactions with Bacterial Activity, Procedia Chem. 7 (2012) 641-646. https://doi.org/10.1016/j.proche.2012.10.097.

[4] M. Saheb, D. Neff, P. Dillmann, H. Matthiesen, E. Foy, Long-term corrosion behaviour of lowcarbon steel in anoxic environment: Characterisation of archaeological artefacts, J. Nucl. Mater. 379 (2008) 118-123. https://doi.org/10.1016/j.jnucmat.2008.06.019.

[5] Y. Fors, F. Jalilehvand, E. Damian Risberg, C. Björdal, E. Phillips, M. Sandström, Sulfur and iron analyses of marine archaeological wood in shipwrecks from the Baltic Sea and Scandinavian waters, J. Archaeol. Sci. 39 (2012) 2521-2532. https://doi.org/10.1016/j.jas.2012.03.006.

[6] H.T.K.J.M.A.W.S.M.F. Dinh, Iron corrosion by novel anaerobic microorganisms, Nature. 427 (2004) 829-832. https://doi.org/10.1038/nature02321.

[7] H. Li, E. Zhou, D. Zhang, D. Xu, J. Xia, C. Yang, H. Feng, Z. Jiang X. Li, T Gu, Microbiologically influenced corrosion of 2707 hyper-duplex stainless steel by marine Pseudomonas aeruginosa biofilm, Sci. Rep. 6 (2016) 20190.

[8] H. Venzlaff, D. Enning, J. Srinivasan, K.J.J. Mayrhofer, A.W. Hassel, F. Widdel, M. Stratmann, Accelerated cathodic reaction in microbial corrosion of iron due to direct electron uptake by sulfate-reducing bacteria, Corros. Sci. 66 (2013) 88-96. https://doi.org/10.1016/j.corsci.2012.09.006.

[9] R. Jeffrey, R.E. Melchers, Bacteriological influence in the development of iron sulphide species in marine immersion environment, Corros Sci. 45 (2003) 693-714. https://doi.org/10.1016/s0010-938x(02)00147 6.

[10] H.L. Ehrlich, Microbes and metals, Appl Microbiol. Biotechnol. 48 (1997) 687-692.

[11] W. Lee, Z. Lewandowski, P.H. Nielsen, W.A. Hamilton, Role of sulfate-reducing bacterie in corrosion of mild steels: a review, Biofouling. 8 (1995) 165-194.

[12] S. Kakooei, M.C. Ismail, B. Ariwahj edi, Mechanisms of microbiologically influenced corrosion: a review, World Appl Sci. J. 17 (2012) 524.

[13] R.A. King, J.D.A. Miller, Corrosion by the sulphate-reducing bacteria, Nature. 233 (1971) 491-492.

[14] M.L. Schlegel, C. Bata llon, C Blanc, D. Prêt, E. Foy, Anodic Activation of Iron Corrosion in Clay Media under Water Saturated Conditions at $90^{\circ} \mathrm{C}$ : Characterization of the Corrosion Interface, Envir n. S i. Technol. 44 (2010) 1503-1508. https://doi.org/10.1021/es9021987.

[15] M. Saheb, D. Neff, J. Demory, E. Foy, P. Dillmann, Characterisation of corrosion layers formed on fer ous archaeological artefacts buried in anoxic media, Corros. Eng. Sci. Technol. 45 (2010) 381-387. https://doi.org/10.1179/147842210x12772898886889.

[16] F King Corrosion of carbon steel under anaerobic conditions in a repository for SF and HLW in Opalinus Clay. Technical report 08-12, Integrity Corrosion Consulting Ltd, 2008.

[17] V. Fe 1, M. Ward, Iron sulphides : Corrosion products on artifacts from waterlogged deposits, in: W. Mourey, L. Robbiola (Eds.), Met. 98 Conf. Met. Conserv., James and James, Draguignan-Figanières, France, 1998: pp. 111-115.

[18] C. Rémazeilles, M. Saheb, D. Neff, E. Guilminot, K. Tran, J.-A. Bourdoiseau, R. Sabot, M. Jeannin, H. Matthiesen, P. Dillmann, P. Refait, Microbiologically influenced corrosion of archaeological artefacts: characterisation of iron(II) sulfides by Raman spectroscopy, J. Raman Spectrosc. 41 (2010) 1425-1433. https://doi.org/10.1002/jrs.2717.

[19] R.A. King, J.D.A. Miller, Corrosion of mild steel by iron sulfides, Br. Corros. J. 8 (1973).

[20] D.W. Shoesmith, P. Taylor, M.G. Bailey, D.G. Owen, The Formation of Ferrous Monosulfide Polymorphs during the Corrosion of Iron by Aqueous Hydrogen Sulfide at $21^{\circ} \mathrm{C}$, J. 
Electrochem. Soc. 127 (1980) 1007-1015. https://doi.org/10.1149/1.2129808.

[21] W. Sun, S. Nešić, A Mechanistic Model of Uniform Hydrogen Sulfide/Carbon Dioxide Corrosion of Mild Steel, Corrosion. 65 (2009) 291-307. https://doi.org/10.5006/1.3319134.

[22] A.G. Wikjord, T.E. Rummery, F.E. Doern, D.G. Owen, Corrosion and deposition during the exposure of carbon steel to hydrogen sulphide-water solutions, Corros. Sci. 20 (1980) 651-671. https://doi.org/10.1016/0010-938X(80)90101-8.

[23] Y. Zheng, B. Brown, S. Nešić, Electrochemical Study and Modeling of H2S Corrosion of Mild Steel, Corrosion. 70 (2013) 351-365. https://doi.org/10.5006/0937.

[24] R.W. Revie, Corrosion and corrosion control: an introduction to corrosion science and engineering, John Wiley \& Sons, 2008.

[25] H.A. Videla, Prevention and control of biocorrosion, Int. Biodeterior. Biodegrad. 49 (2002) 259-270. https://doi.org/10.1016/s0964-8305(02)00053-7.

[26] G. Muyzer, A.J.M. Stams, The ecology and biotechnology of sulphate-reducing bacteria, Nat. Rev. Microbiol. 6 (2008) 441-454. https://doi.org/10.1038/nrmicro1892.

[27] J.R. Postgate, The Sulphate-Reducing Bacteria, CUP Archive, 1979.

[28] D. Rickard, G.W. Luther, Chemistry of Iron Sulfides, Chem. Rev. 107 (2007) 514-562 https://doi.org/10.1021/cr0503658.

[29] L.G. Benning, R.T. Wilkin, H.L. Barnes, Reaction pathways in the Fe-S system below $100^{\circ} \mathrm{C}$, Chem. Geol. 167 (2000) 25-51. https://doi.org/10.1016/s0009-2541(99)00198-9.

[30] N.G. Harmandas, P.G. Koutsoukos, The formation of iron(II) sulfides in queou solutions, J. Cryst. Growth. 167 (1996) 719-724. https://doi.org/10.1016/0022-0248(96)00257-6.

[31] S. Hunger, L.G. Benning, Greigite : a true intermediate on the polysulfide pathway to pyrite, Geochem. Trans. (2007) 1-20. http://files/269/Hunger_et_al_2007.pdf.

[32] M.A.A. Schoonen, H.L. Barnes, Reactions forming pyrite and marcasi e from solution: I. Nucleation of $\mathrm{FeS} 2$ below $100^{\circ} \mathrm{C}$, Geochim. Cosmochim. Acta. 55 (1991) 1495-1504. https://doi.org/10.1016/0016-7037(91)90122-L.

[33] I.B. Butler, D. Rickard, Framboidal pyrite formation via the oxidation of iron (II) monosulfide by hydrogen sulphide, Geochim. Cosmochim. Acta. 64 (2000) 2665-2672. https://doi.org/10.1016/s0016-7037(00)00387-2.

[34] M. Langumier, R. Sabot, R. Obame-Ndong, M Jeannin, S. Sablé, P. Refait, Formation of $\mathrm{Fe}(\mathrm{III})$-containing mackinawite from hydroxysulphate green rust by sulphate reducing bacteria, Corros. Sci. 51 (2009) 2694-2702. https:// oi.org/10.1016/j.corsci.2009.07.001.

[35] B.W.A. Sherar, I.M. Power, P.G. Keech, S. Mitlin, G. Southam, D.W. Shoesmith, Characterizing the effect of carbon steel exposure in sulfide containing solutions to microbially induced corrosion, Corros. Sci. 5 (2011) 955-960. https://doi.org/10.1016/j.corsci 201011.027.

[36] C. Kendall, E.A. Caldwell, Fundamentals of Isotope Geochemistry, in: Isot. Tracers Catchment Hydrol., C. Kendall a d J.J. McDonnell, Amsterdam, n.d.: pp. 51-86.

http://files/1094/Fundam ntals of Isotope Geochemistry.pdf files/1095/Fundamentals of Isotope Geochemis y.pdf.

[37] B. Brunner, S.M. Bernasconi, A revised isotope fractionation model for dissimilatory sulfate reduction in ulfate reducing bacteria, Geochim. Cosmochim. Acta. 69 (2005) 4759-4771. https://doi.org/10 1016/j.gca.2005.04.015.

[38] C.E. Rees, A steady-state model for sulphur isotope fractionation in bacterial reduction pr cesse Geochim. Cosmochim. Acta. 37 (1973) 1141-1162. https://doi.org/10.1016/00167037 73)90052-5.

[39] D.E. Canfield, Biogeochemistry of sulfur isotopes, Rev. Mineral. Geochemistry. 43 (2001) 607-636.

[40] M.S. Sim, T. Bosak, S. Ono, Large Sulfur Isotope Fractionation Does Not Require Disproportionation, Science (80-. ). 333 (2011) 74-77. https://doi.org/10.1126/science.1205103.

[41] D.E. Canfield, Isotope fractionation by natural populations of sulfate-reducing bacteria, Geochim. Cosmochim. Acta. 65 (2001) 1117-1124. https://doi.org/10.1016/s00167037(00)00584-6.

[42] M.C. Stam, P.R.D. Mason, C. Pallud, P. Van Cappellen, Sulfate reducing activity and sulfur 
isotope fractionation by natural microbial communities in sediments of a hypersaline soda lake (Mono Lake, California), Chem. Geol. 278 (2010) 23-30.

https://doi.org/10.1016/j.chemgeo.2010.08.006.

[43] J. Kleikemper, M.H. Schroth, S.M. Bernasconi, B. Brunner, J. Zeyer, Sulfur isotope fractionation during growth of sulfate-reducing bacteria on various carbon sources, Geochim. Cosmochim. Acta. 68 (2004) 4891-4904. https://doi.org/10.1016/j.gca.2004.05.034.

[44] H.G. Thode, J. Monster, H.B. Dunford, Sulphur isotope geochemistry, Geochim. Cosmochim. Acta. 25 (1961) 159-174. https://doi.org/10.1016/0016-7037(61)90074-6.

[45] G. Antler, A. V Turchyn, V. Rennie, B. Herut, O. Sivan, Coupled sulfur and oxygen isotope insight into bacterial sulfate reduction in the natural environment, Geochim. Cosmochim. Acta. 118 (2013) 98-117. https://doi.org/10.1016/j.gca.2013.05.005.

[46] M.C. Stam, P.R.D. Mason, A.M. Laverman, C. Pallud, P. Van Cappellen, 34S/32S fractionation by sulfate-reducing microbial communities in estuarine sediments, Geochim. Cosmochim. Acta. 75 (2011) 3903-3914. https://doi.org/10.1016/j.gca.2011.04.022.

[47] C. Lerouge, S. Grangeon, E.C. Gaucher, C. Tournassat, P. Agrinier, C. Guerrot, D. Widory, C. Fléhoc, G. Wille, C. Ramboz, A. Vinsot, S. Buschaert, Mineralogical and isotopic record of biotic and abiotic diagenesis of the Callovian-Oxfordian clayey formation of Bure (Franc ), Geochim. Cosmochim. Acta. (2011). https://doi.org/10.1016/j.gca.2011.02.025

[48] B. Little, P. Wagner, J. Jones-Meehan, Sulfur isotope fractionation by sulfat red cing bacteria in corrosion products, Biofouling. 6 (1993) 279-288. https://doi.org/10.1080/08927019309386229.

[49] S. Grousset, M. Bayle, A. Dauzeres, D. Crusset, V. Deydier, Y. Linard P. Dillmann, F. Mercier-Bion, D. Neff, Study of iron sulphides in long-term iron corrosi n processes: Characterisations of archaeological artefacts, Corros. Sci. 112 2016) 264-275. https://doi.org/http://dx.doi.org/10.1016/j.corsci.2016.07.022.

[50] A. Seyeux, P. Marcus, Analysis of the chemical or bacterial rigin of iron sulfides on steel by time of flight secondary ion mass spectrometry (ToF SIMS), Corros. Sci. 112 (2016) 728-733. https://doi.org/10.1016/j.corsci.2016.09.008.

[51] A.-I. El Menjra, A. Seyeux, D. Mercier, I Beech Z. Makama, P. Marcus, ToF-SIMS analysis of abiotic and biotic iron sulfide layers formed in aqueous conditions on iron surfaces, Appl. Surf. Sci. 484 (2019) 876-883. https://d i.org/https://doi.org/10.1016/j.apsusc.2019.04.154.

[52] B.W.A. Sherar, P.G. Keech, J.J. Noël, R.G Worthingham, D.W. Shoesmith, Effect of Sulfide on Carbon Steel Corrosion in An erobic Near Neutral pH Saline Solutions, CORROSION. 69 (2012) 67-76. https://doi.org/10.5006/0687.

[53] S. Berlendis, M. Ranchou-Peyrus M. L. Fardeau, J.-F. Lascourrèges, M. Joseph, B. Ollivier, T. Aüllo, D. Dequidt, M. Magot, A. Ranchou-Peyruse, Desulfotomaculum aquiferis sp. nov. and Desulfotomaculum profundi sp. nov. isolated from a deep natural gas storage aquifer, Int. J. Syst. Evol. Microbi . (2016). https://doi.org/10.1099/ijsem.0.001352.

[54] J. Tremosa, D. Arcos, J.M. Matray, F. Bensenouci, E.C. Gaucher, C. Tournassat, J. Hadi, Geochemical chara terization and modelling of the Toarcian/Domerian porewater at the Tournemire underground research laboratory, 25 Years after Chernobyl Power Plant Explos. Manag. Nucl Waste Radionucl. Transf. Environ. 27 (2012) 1417-1431. https://doi.org/10 1016/j.apgeochem.2012.01.005.

[55] J M. Matray, S. Savoye, J. Cabrera, Desaturation and structure relationships around drifts ex avat d in the well-compacted Tournemire's argillite (Aveyron, France), Eng. Geol. 90 (200 ) 1-16. https://doi.org/10.1016/j.enggeo.2006.09.021.

[56] C. Beaucaire, J.-L. Michelot, S. Savoye, J. Cabrera, Groundwater characterisation and modelling of water-rock interaction in an argillaceous formation (Tournemire, France), Appl. Geochemistry. 23 (2008) 2182-2197. https://doi.org/10.1016/j.apgeochem.2008.03.003.

[57] O. Haouari, M.-L. Fardeau, J.-L. Cayol, G. Fauque, C. Casiot, F. Elbaz-Poulichet, M. Hamdi, B. Ollivier, Thermodesulfovibrio hydrogeniphilus sp. nov., a new thermophilic sulphatereducing bacterium isolated from a Tunisian hot spring, Syst. Appl. Microbiol. 31 (2008) 3842. https://doi.org/10.1016/j.syapm.2007.12.002.

[58] C. Jeanthon, A.-L. Reysenbach, S. L'Haridon, A. Gambacorta, N.R. Pace, P. Glénat, D. Prieur, Thermotoga subterranea sp. nov., a new thermophilic bacterium isolated from a continental oil 
reservoir, Arch. Microbiol. 164 (1995) 91-97. https://doi.org/10.1007/s002030050239.

[59] G. Beaudoin, B.E. Taylor, D. Rumble Iii, M. Thiemens, Variations in the sulfur isotope composition of troilite from the Cañon Diablo iron meteorite, Geochim. Cosmochim. Acta. 58 (1994) 4253-4255. https://doi.org/10.1016/0016-7037(94)90277-1.

[60] Y. Leon, M. Saheb, E. Drouet, D. Neff, E. Foy, E. Leroy, J.J. Dynes, P. Dillmann, Interfacial layer on archaeological mild steel corroded in carbonated anoxic environments studied with coupled micro and nano probes, Corros. Sci. 88 (2014) 23-35. https://doi.org/10.1016/j.corsci.2014.07.005.

[61] P. Hoppe, S. Cohen, A. Meibom, NanoSIMS: Technical Aspects and Applications in Cosmochemistry and Biological Geochemistry, Geostand. Geoanalytical Res. 37 (2013) 111154. https://doi.org/10.1111/j.1751-908X.2013.00239.x.

[62] G. Slodzian, Challenges in localized high precision isotope analysis by SIMS, Appl. Surf. Sci. 231-232 (2004) 3-12. https://doi.org/10.1016/j.apsusc.2004.03.015.

[63] G. Slodzian, F. Hillion, F.J. Stadermann, E. Zinner, QSA influences on isotopic ratio measurements, Appl. Surf. Sci. 231-232 (2004) 874-877. https://doi.org/10.1016/j.apsusc.2004.03.155.

[64] B. Winterholler, P. Hoppe, S. Foley, M.O. Andreae, Sulfur isotope ratio measureme ts of individual sulfate particles by NanoSIMS, Int. J. Mass Spectrom. 272 (2008) 63-77. https://doi.org/10.1016/j.ijms.2008.01.003.

[65] H.G. Thode, Sulphur isotopes in Nature and the Environment: an overview., in: Stable Isot. Assess. Nat. Anthropog. Sulphur Environ., John Wiley and Sons Ltd. 1991 http://files/704/Thode_Chapitre_I_d'un_livre_1991.pdf.

[66] S. Oana, H. Ishikawa, Sulfur isotopic fractionation between sulfur and sulfuric acid in the hydrothermal solution of sulfur dioxide, Geochem. J. 1 (1966) 45-50. https://doi.org/10.2343/geochemj.1.45.

[67] C. Chautard, Intéractions fer/argile en conditions de sotckage géologique profond - Impacts d'activités bactériennes et d'hétérogénéités, Ecole nationale supérieure des mines de Paris, 2013.

[68] D.E. Canfield, B. Thamdrup, S. Fleischer, I otop fractionation and sulfur metabolism by pure and enrichment cultures of elemental sufur-disprop rtionating bacteria, Limnol. Oceanogr. 43 (n.d.) 253-264. http://files/58/Canfield_t_al_1998.pdf.

[69] C. Chautard, Interactions fer/argile en conditions de stockage géologique profond - Impacts d'activités bactériennes et d'hétérogénéités, Ecole nationale supérieure des mines de Paris, 2013.

[70] R.A. Berner, Sedimentary pyrite forma ion: an update, Geochim. Cosmochim. Acta. 48 (1984) 605-615. 
Table 1 : Sulphur isotopic fractionation of iron sulphides in (A), (B) and (B-A) (NanoSIMS analyses) expressed relative to the $C D T, \delta^{34} S_{\text {sulphides-CDT }}(\%)$, and relative to the sulphur isotopic composition of the sulphates of the medium $\delta^{34} S_{\text {sulphides-sulphates }}(\% \circ)$.

\begin{tabular}{|l|l|l|l|l|l|l|l|l|}
\hline Coupon & $\mathrm{A} 1-\mathrm{a}$ & $\mathrm{A} 1-\mathrm{b}$ & $\mathrm{A} 2-\mathrm{a}$ & $\mathrm{A} 2-\mathrm{b}$ & $\mathrm{A} 2-\mathrm{c}$ & $\mathrm{A} 2-\mathrm{d}$ & & \\
\hline$\delta^{34} \mathrm{~S}_{\text {sulphides-CDT }}(\%)$ & $10.3 \pm 6.4$ & $14.2 \pm 5.7$ & $7.7 \pm 6.1$ & $4.8 \pm 6.2$ & $12.3 \pm 6.4$ & $13.0 \pm 6.4$ & & \\
\hline$\delta^{34} \mathrm{~S}_{\text {sulphides-sulphates }}(\%)$ & $10.6 \pm 6.4$ & $14.5 \pm 5.7$ & $7.7 \pm 6.1$ & $4.8 \pm 6.2$ & $12.3 \pm 6.4$ & $13.0 \pm 6.4$ & & \\
\hline Coupon & $\mathrm{B}-\mathrm{a}$ & $\mathrm{B}-\mathrm{b}$ & & & & & & \\
\hline$\left.\delta^{34} \mathrm{~S}_{\text {sulphides-CDT }} \% \mathrm{o}\right)$ & $-24.6 \pm 5.2$ & $-25.5 \pm 6.4$ & & & & & & \\
\hline$\delta^{34} \mathrm{~S}_{\text {sulphides-sulphates }}(\%)$ & $-24.7 \pm 5.2$ & $-25.5 \pm 6.4$ & & & & & & \\
\hline Coupon & $\mathrm{B}-\mathrm{A} 1$ & $\mathrm{~B}-\mathrm{A} 2$ & $\mathrm{~B}-\mathrm{A} 3$ & $\mathrm{~B}-\mathrm{A} 4-\mathrm{a}$ & $\mathrm{B}-\mathrm{A} 4-\mathrm{b}$ & $\mathrm{B}-\mathrm{A} 5$ & & \\
\hline$\left.\delta^{34} \mathrm{~S}_{\text {sulphides-CDT }} \% \mathrm{\%}\right)$ & $-29.5 \pm 6.5$ & $-8.7 \pm 6.6$ & $-26.0 \pm 4.9$ & $-12.4 \pm 4.9$ & $-25.0 \pm 5.0$ & $-7.2 \pm 6.2$ & & \\
\hline$\delta^{34} \mathrm{~S}_{\text {sulphides-sulphates }}(\%)$ & $-29.6 \pm 6.5$ & $-9.7 \pm 6.6$ & $-28.1 \pm 4.9$ & $-9.8 \pm 4.9$ & $-22.5 \pm 5.0$ & $-7.5 \pm 6.2$ & & \\
\hline
\end{tabular}

Table 2 : Sulphur isotopic fractionation of iron sulphides in CBCC experiment (NanoSIMS analyses) expressed relative to the $C D T, \delta^{34} S_{\text {sulphides-CDT }}(\% \circ)$, and relative to the sulphur isotopic composition of the sulphates of the medium, $\delta^{34} S_{\text {sulphides-sulphates }}(\%)$.

\begin{tabular}{|l|l|l|l|}
\hline Coupon & CBCC1 & CBCC2 & CBCC3 \\
\hline$\delta^{34} S_{\text {sulphides-CDT (\%o) }}$ & $-4.9 \pm 5.0$ & $-4.4 \pm 4.5$ & $-4.0 \pm 4.7$ \\
\hline$\delta^{34} S_{\text {sulphides-sulphates }}(\% \circ)$ & $-4.0 \pm 5.0$ & $-3.5 \pm 4.5$ & $-3.1 \pm 4.7$ \\
\hline
\end{tabular}




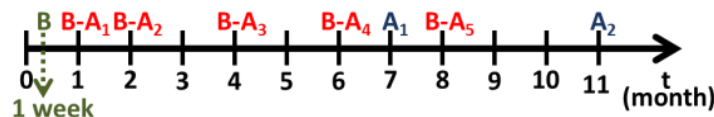

Figure 1: Schematic diagram of the duration for abiotic (A), biotic (B) and biotic-abiotic (B-A) experiments.

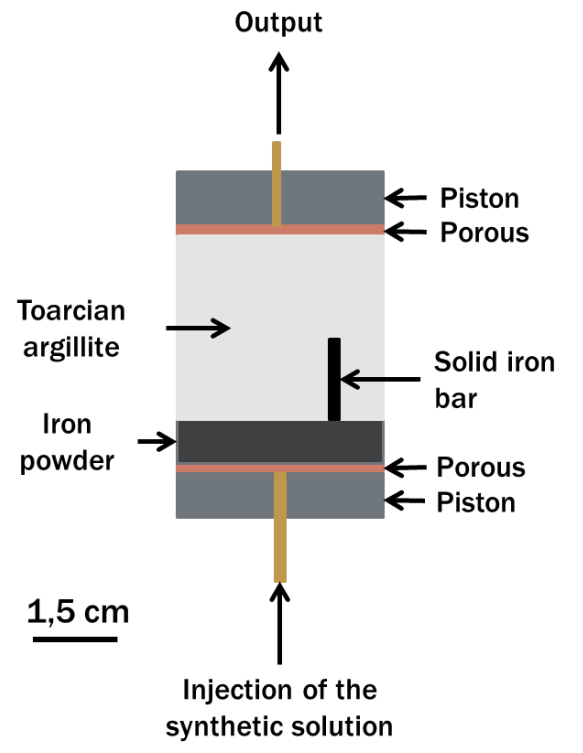

Figure 2: Biotic percolation cell 3.

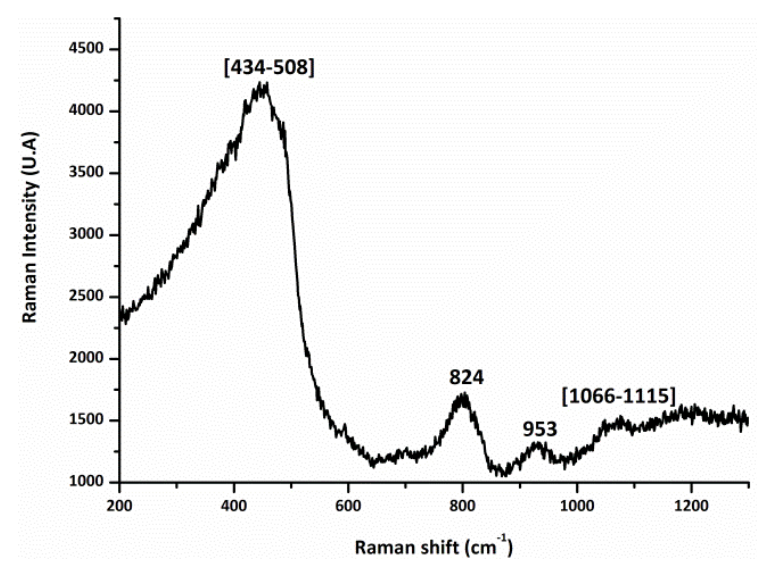

Figure 3: Raman spectrum of the anoxic cell glass. 


\section{$34 S / 32 S$}

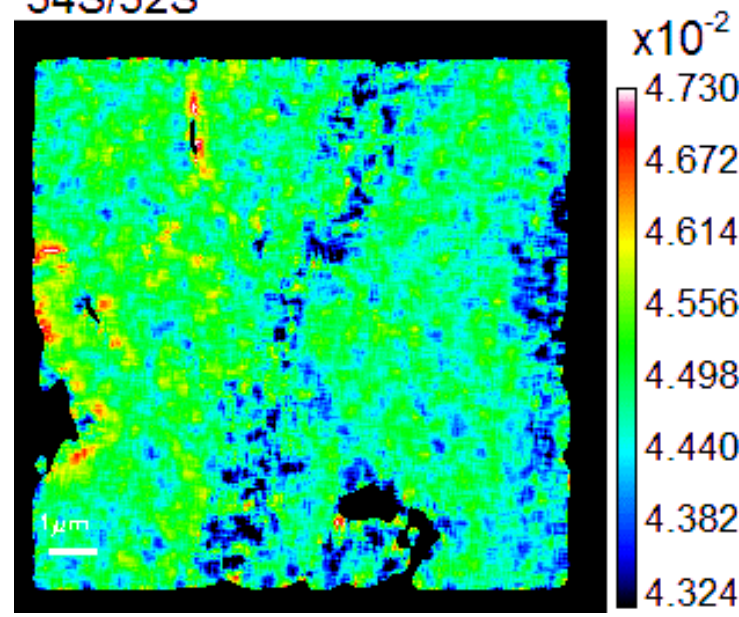

Figure 4: Example of a collected NanoSIMS map showing the 34S/32S ratio on the CBCC sample.

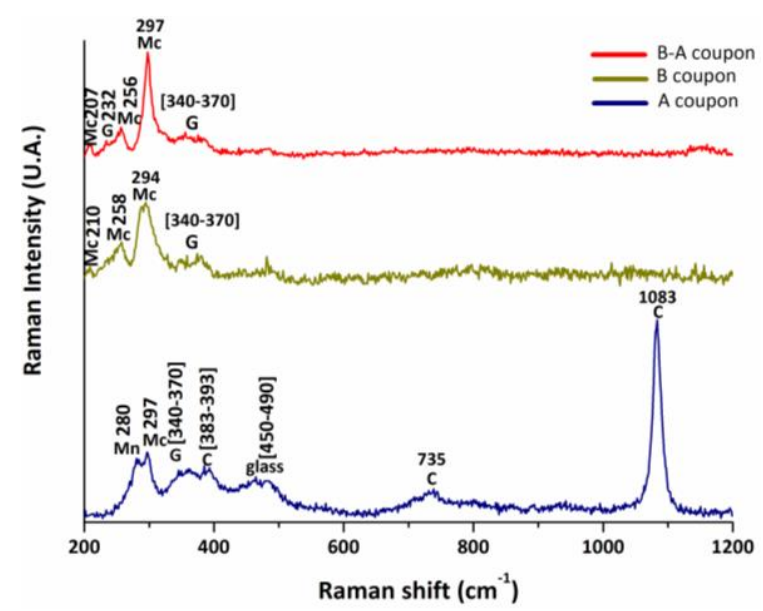

Figure 5: Raman spectrum obtai ed in an anoxic cell set-up on a (A) coupon (11 months), a (B) coupon (7 days) and a (B-A) coupon (8 months). Mn: $n$ nocrystalline mackinawite; Mc: crystalline mackinawite; G: greigite; C; carbonates.

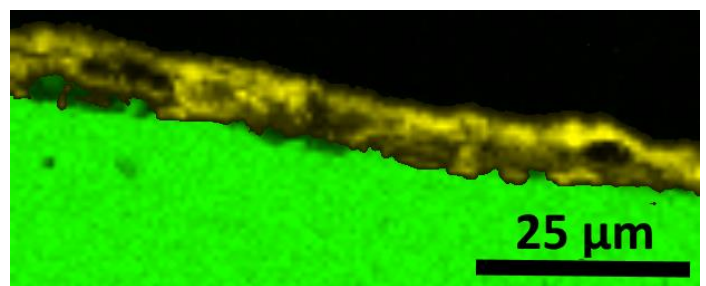

Figure 6: Superposition of Fe $K_{\alpha}$ (green) and $S K_{\alpha}$ (yellow) EDS maps (15 keV) obtained on the cross-section of an A coupon (11 months). 


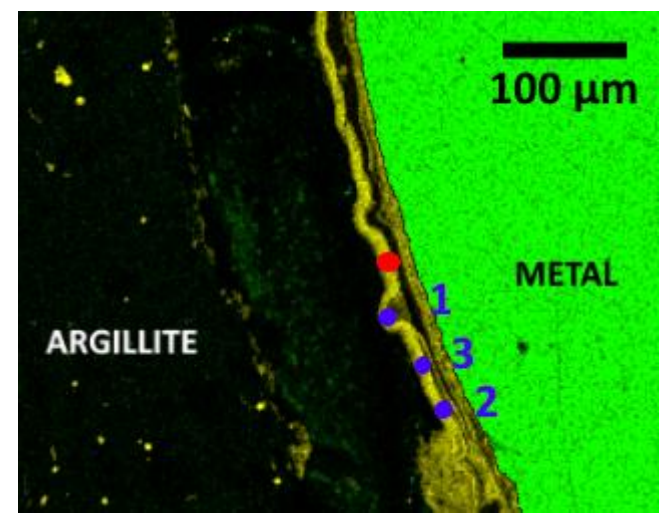

Figure 7: Superposition of Fe $\mathrm{K}_{\alpha}$ (green), $\mathrm{S} \mathrm{K}_{\alpha}$ (yellow) EDS maps obtained on CBCC's cross-section. Points 1, 2 and 3 represent the location of the sulphur isotopic analyses 1,2 and 3 of the CBCC sample in the Figure 9.

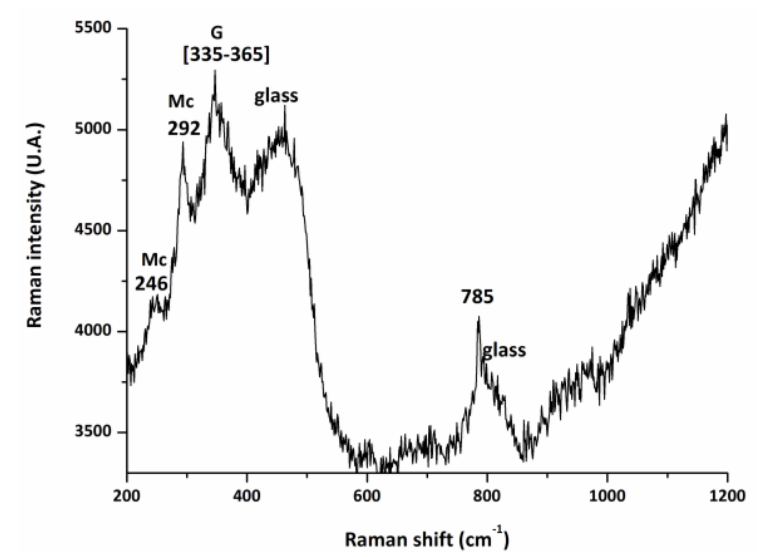

Figure 8: Raman spectrum obtained on cross-section of CBCC samp e Mc: crystalline mackinawite; G: greigite (anoxic cell set-up).

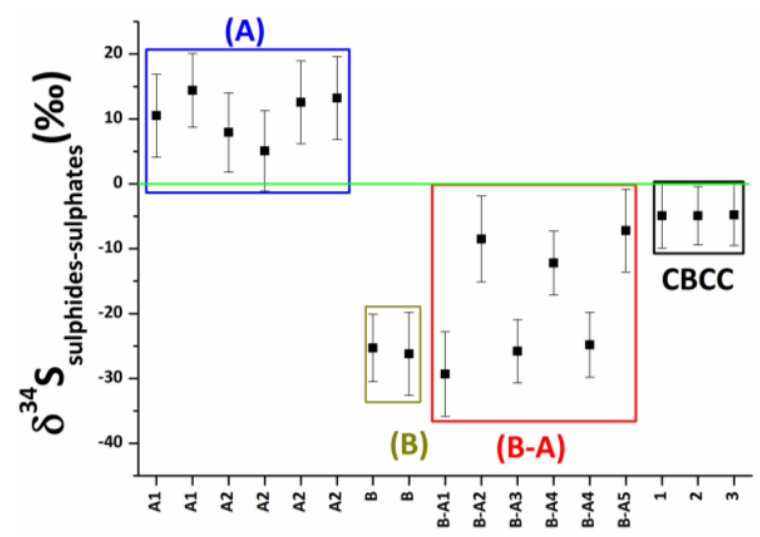

F ure 9 Sulphu isotopic fractionation of iron sulphides in (A), (B), (B-A) and CBCC experiments (NanoSIMS analyses) expressed elative to the sulphur isotopic composition of the sulphates in their respective medium (CF-IRMS analyses). 